This is an Accepted Manuscript of an article published by Taylor \& Francis in Total Quality Management and Business Excellence on 30 Nov 2018, available online: http://

www.tandfonline.com/10.1080/14783363.2018.1549938.

\title{
ISO 9000, Activity Based Costing and Organizational Performance
}

\author{
Witchulada Vetchagool ${ }^{1}$, Marcjanna M. Augustyn ${ }^{2}$, Mike Tayles $^{3}$
}

\begin{abstract}
This study investigates the potential complementarity between ISO 9000 and Activity Based Costing $(\mathrm{ABC})$. This is undertaken by examining associations between the extent of ISO 9000 implementation and the extent of $\mathrm{ABC}$ use and by examining the impact on organizational performance of the extent of ISO 9000 implementation in organizations that have adopted both ISO 9000 and ABC (ABC Firms) as compared to those that have only adopted ISO 9000 (Non-ABC Firms).
\end{abstract}

Correlation analysis and a multi-group analysis in structural equation modelling (SEM) are employed using quantitative data from a cross-sectional mail survey of 601 Thai ISO 9001-registered organizations. The results indicate that there are significant positive correlations between ISO 9000 and ABC activities, and that the impact of ISO 9000 implementation on organizational performance is significantly stronger for ABC Firms than that for Non-ABC Firms.

\footnotetext{
${ }^{1}$ Lecturer, Faculty of Business Administration and Accountancy, Khon Kaen University, Khon Kaen, 40002 Thailand, Email: witchulada@kku.ac.th

${ }^{2}$ Senior Lecturer, Marketing and Business Strategy, Hull University Business School, The University of Hull, Hull, HU6 7RX, United Kingdom, Email: m.augustyn@hull.ac.uk

${ }^{3}$ Emeritus Professor of Accounting and Finance, Hull University Business School, The University of Hull, Hull, HU6 7RX, United Kingdom. Visiting Professor, University of Thai Chamber of Commerce, Bangkok, Thailand, Email: m.e.tayles@ hull.ac.uk
} 
The results generate new evidence that advances knowledge of complementarity between ISO 9000 and ABC and the effects of ISO 9000 on organizational performance. The findings have significance for researchers evaluating the use of ISO 9000 and $\mathrm{ABC}$ in concert with other organizational initiatives and for practitioners who could consider the benefits of concurrent implementation of both systems in reviewing/designing performance improvement systems.

\section{Keywords:}

ISO 9000, Activity Based Costing (ABC), Operational Performance, Financial Performance, Complementarity, Quality Management, Structural Equation Modelling $(\mathrm{SEM})$

\section{Research paper}




\section{Introduction}

The ISO 9000 family of international standards and guidelines for developing and implementing a quality management system (QMS) is designed to help organizations attain continual improvement and business excellence (ISO, 2017). It is not surprising therefore that the impact of ISO 9000 on organizational performance has received considerable research attention since the launch of ISO 9000 in 1987.

Literature indicates that despite the continuing debate on the effects of ISO 9000 (Dick, 2000; Wu and Chen, 2012), scholars generally agree that in the absence of implementation failures, comprehensive implementation of ISO 9000 may positively impact organizational performance (Chow-Chua et al., 2003; Psomas and Fotopoulos, 2009; Gotzamani, 2010; Kusumah and Fabianto, 2018). ISO 9000 is one of several management methods for improving business performance. Furthermore, some of these methods may be complementary (Naveh and Marcus, 2005; Benner and Veloso, 2008; Ennen and Richter, 2010; Aba et al., 2016). However, little is known about concurrent use of other performance improvement methods with ISO 9000 and whether this increases the impact of ISO 9000 on performance.

Among the few scholars who indicated the importance of concurrent use of ISO 9000 and other performance improvement methods, Larson and Kerr $(2002,2007)$ suggested that ISO 9000 and Activity Based Costing (ABC) may be complementary because both ISO 9000 and $\mathrm{ABC}$ support the process view of management and the underlying processes that are needed to implement ISO 9000 and ABC are similar. Consequently, implementation of both ISO 9000 and ABC may result in better 
organizational performance than implementation of one system only (Larson and Kerr, $2002,2007)^{4}$.

Theoretically, complementarity between ISO 9000 and ABC is likely because both are oriented towards continuous performance improvement (Bescos and Charaf, 2013; ISO 2016). Furthermore, research findings in both the quality management literature and the management accounting literature indicate that extensive use of ISO 9000 and ABC respectively may positively impact organizational performance (Naveh and Marcus, 2005; Banker et al., 2008; Jain and Ahuja, 2012; Maiga, 2014; Miryazdi and Jusoh, 2015; Kusumah and Fabianto, 2018). Additionally, literature suggests that there could be several interactions between ISO 9000 and ABC that could enhance each other's value and effect on performance, mainly in the area of information exchange (Intakhan, 2014). Thus when viewed from the perspective of complementarities in organizations (Milgrom and Roberts, 1995; Ennen and Richter, 2010), the features of ISO 9000 and ABC and the existence of interactions between them indicate that ISO 9000 and ABC could be complementary.

Despite its theoretical plausibility and relevance to managerial practice, the proposition of complementarity between ISO 9000 and ABC has received remarkably little attention in empirical studies. The existing evidence provided by Larson and Kerr (2002, 2007 ) is derived from their exploratory study into combined effects of ISO 9000 and ABC. However, their empirical results contradict their complementarity hypothesis as discussed in Section 2 of this paper. Our literature review revealed no further research on complementarity between ISO 9000 and ABC. Thus there is a gap in our understanding of this relationship. Therefore, this study aims to investigate potential complementarity between ISO 9000 and Activity Based Costing (ABC). This is undertaken by examining

\footnotetext{
${ }^{4}$ While Larson and Kerr's (2002, 2007) research addressed ISO 9000:2000, the current research is mobilized with reference to ISO 9000:2008. However, the changes to the ISO 9000 family of standard introduced since 2000 have no implications for examining the ISO 9000 - ABC complementarity hypothesis as the key characteristics of ISO 9000 discussed in this paper have remained unchanged.
} 
the impact of the extent of ISO 9000 implementation on organizational performance in organizations that have adopted both ISO 9000 and ABC (ABC Firms) and organizations that have only adopted ISO 9000 (Non-ABC Firms).

In this study, quantitative data from a cross-sectional mail survey of 601 Thai ISO 9001-registered organizations is analysed using Pearson's correlation analysis and a multigroup analysis in structural equation modelling (SEM). The results of this study generate new evidence that closes an important gap in knowledge of complementarity between ISO 9000 and $\mathrm{ABC}$ and the effects of ISO 9000 on organizational performance. Specifically, this is the first major empirical study that investigates the potential complementarity between ISO 9000 and $\mathrm{ABC}$ using this methodology. The findings have significance for researchers evaluating the use of ISO 9000 and ABC in concert with other organizational initiatives and for practitioners who are implementing performance improvement systems such as ISO 9000 and ABC.

The rest of the paper is organized as follows. In the next section the literature on ISO 9000, ABC, organizational performance and the complementarities perspective is reviewed and leads to the development of our hypotheses. We next describe the research methodology and report descriptive statistics from which the research findings are presented. The final two sections discuss the implications of the findings and draw conclusions including reference to theoretical contribution of the study, practical implications as well as limitations and potential for further research. 


\section{Literature review and hypothesis development}

\subsection{ISO 9000 and organizational performance}

The ISO 9000 family of international standards and guidelines provides a basis for developing and implementing a quality management system (QMS) and collectively helps organizations attain continual improvement and business excellence. Within the family, ISO 9001 specifies the basic requirements of a QMS and is used for certification purposes while ISO 9004 provides guidelines for managing quality to sustain success. Since its launch in 1987, the various components of the ISO 9000 family have been periodically reviewed to reflect advancements in the quality management field and user feedback (Gotzamani, 2010; ISO, 2017).

ISO 9000 is underpinned by quality management principles that collectively should lead to improving performance (ISO, 2016). Until 2015, there were eight principles namely: customer focus; leadership; involvement of people; process approach; system approach to management; continual improvement; factual approach to decision-making; mutually beneficial supplier relationship (ISO, 2012). The latest (2015) edition of the standard reduced the number of quality management principles to seven (ISO, 2015) because the former principle of system approach to management is now contained within the "process approach" principle. The names of some principles were also changed in 2015 and the current seven principles of quality management are: customer focus; leadership; engagement of people; process approach; improvement; evidence-based decision making; relationship management (ISO, 2015). Although the structure and terminology of the quality management principles changed in 2015 , their strategic intent — "to guide an organization's performance improvement" (ISO, 2015, p. 1)—remained the same. 
Using diverse operationalisations of study constructs and various methodologies, some empirical studies examined the impact of implementing ISO 9000 on organizational performance. For example, in a study of 924 U.S. ISO 9001 certified firms, Naveh and Marcus (2005) found that the extent of ISO 9000 usage (in daily practice and as a catalyst for change) was positively related to operational performance and business performance. However, the indirect relationship between the extent of usage of ISO 9000 and business performance through operational performance was not fully supported because of the insignificant effect of operational performance on one of the measures of business performance (gross profit margin). In contrast, Jang and Lin (2008) observed that the extent of ISO 9000 implementation (measured by eight management practices related to ISO 9000) had a direct effect on operational performance and indirect effect (through operational performance and market performance) on financial performance of 441 Taiwanese ISO 9001 certified organizations. Furthermore, based on a study of 96 manufacturing firms in India, Jain and Ahuja (2012) reported that extensive implementation of ISO 9000 impacted on manufacturing performance and, in particular, that continuous improvement and customer focus could be more influential in improving operational performance. Meanwhile, Lee et al. (2009) explored the impact of implementation patterns of ISO 9000:2000 principles on performance of 45 ISO 9000 certified service organizations in Macao. Their findings indicated that organizations with high levels of implementing ISO 9000 principles outperformed those with low levels of implementing ISO 9000 principles. Furthermore, Kusumah and Fabianto (2018) examined 27 manufacturing companies listed on the Indonesian Stock Exchange. They found that firms that are committed to consistent implementation of ISO 9000 tend to improve financial performance over five years, relative to firms with less consistent ISO 9000 implementation. Taking a different perspective, Alic (2014) studied the adverse impact of ISO 9001 certification cancellation on performance. 
Overall, a review of prior studies indicates that while the results differ with regard to the strength of the ISO 9000 impact on organizational performance, there is a general agreement among scholars that in the absence of implementation failures, comprehensive implementation of ISO 9000 may positively impact organizational performance.

\subsection{Activity based costing (ABC) and organizational performance}

Similar to research findings in the quality management literature, empirical findings in management accounting indicate that use of Activity Based Costing ( $\mathrm{ABC}$ ) may positively impact organizational performance (Bescos and Charaf, 2013; Hardan and Shatnawi, 2013; Miryazdi and Jusoh, 2015).

$\mathrm{ABC}$ was initially promoted as a basis for improving costing accuracy of products or services to assist with pricing and product decisions (Cooper et al., 1992). However it was soon observed that activity based information was valuable in supporting continuous improvement programs, for example in cost management, improving efficiency, cost reduction and generating improved and more relevant performance measures (Turney, 1991; Tsai, 1998; Ozkan and Karaibrahimoglu, 2013). It follows that adopting ABC helps organizations in their decision-making to accomplish organizational performance improvement (Cooper and Kaplan, 1999).

Several empirical studies examined the impact of $\mathrm{ABC}$ use on organizational performance. For example, Kennedy and Affleck-Graves (2001) revealed that U.K. organizations that adopted $\mathrm{ABC}$ accomplished higher abnormal returns compared to organizations that did not adopt ABC. Based on a sample of 2,789 U.S. manufacturing firms, Ittner et al. (2002) reported that while extensive use of ABC had a positive association with non-financial dimensions of quality levels and cycle time, the relationship 
with return on assets was contingent on the plant operational characteristics. Interestingly, Cagwin and Bouwman (2002) found that ABC had a positive relationship with return on investment (ROI) improvement but only when $\mathrm{ABC}$ was employed concurrently with other initiatives. Banker et al. (2008) supported this. The results of their study on the impact of $\mathrm{ABC}$ on costs, quality and time improvement within the context of world-class manufacturing plants indicated that employing $\mathrm{ABC}$ by itself did not lead to performance improvement. They further supported the view of Gupta and Galloway's (2003) that ABC alone might not transform a firm into a world-class competitor but information from $\mathrm{ABC}$ could help a firm make strategic decisions such as quality management (Miryazdi and Jusoh, 2015).

\subsection{Complementarity between ISO 9000 and ABC}

In their efforts to research the combined effects of ISO 9000 and ABC on performance, surprisingly, Larson and Kerr (2002) did not find empirical support for their hypothesis. The researchers found that organizations adopting only ISO 9000 or only ABC outperformed organizations that adopted both ABC and ISO 9000. Based on subsequent interviews at a third-party logistics provider, Larson and Kerr (2002) suggested that the firm could see potential for complementarity of the two performance improvement methods but did not know how to exploit it given that the two systems were implemented by two separate functional departments. Thus, the poorer performance of firms that adopted both ISO 9000 and ABC, vis-à-vis firms that adopted one system only, may have been due to insufficient integration of both systems, duplication of processes and competition between the systems. Indeed, the lack of synchronization between ISO 9000 and ABC found by Larson and Kerr $(2002,2007)$ might have eroded some of the potential complementarity effect. The researchers also noted several limitations of their exploratory 
study, including: (1) sampling limitation (they examined 209 Canadian logistics organizations that included only 20 or $9.6 \%$ of firms that adopted both ISO 9000 and ABC); and (2) use of a single case study only (Larson and Kerr, 2002).

Notwithstanding Larson and Kerr's (2002) results, from the theoretical perspective the hypothesis of complementarity between ISO 9000 and ABC is plausible. To justify this statement, let us first briefly consider the complementarity perspective.

The evolving theory of complementarities in organizations has its roots in economics. Drawing on Edgeworth's work (1881), Milgrom and Roberts (1995, p.181) argued in their seminal paper that complementarity exists if "doing more of one thing increases the returns to doing more of another" (italics in original). Consistent with this view, complementarities exist in organizations when activities interact in such a way that raising the level of one activity $(A B C)$ increases the effects on organizational performance of raising the level of the other activity (ISO 9000) (our italics) (Roberts, 2004; Ennen and Richter, 2010). Since one activity enhances the value of the other one and the effects are mutually reinforcing and multiplying, the total effect on performance of raising the levels of complementary activities is greater than the sum of individual effects, which is known as the complementarity effect (Milgrom and Roberts, 1994; Roberts, 2004).

For the complementarity effect to occur it is therefore essential that activities that are deemed to be complementary have the potential for interaction in such a way that they enhance each other's value and effect on performance. Thus, complementary activities should share some common ground and they should be sufficiently heterogeneous too so that they complement (rather than substitute) each other (Milgrom and Roberts, 1995; Ennen and Richter, 2010). Furthermore, for the complementarity effect to occur the levels of all complementary activities need to be raised; raising the level of only one activity 
could worsen organizational performance (Roberts, 2004; Brynjolfsson and Milgrom, 2013).

In terms of the common ground, empirical evidence suggests that each method may have positive effects on organizational performance (Bescos and Charaf, 2013; ISO 2016) (as discussed in sections 2.1 and 2.2 above). ISO 9000 and ABC are relatively similar in their particular emphasis on managing processes and activities and their documentation (Larson and Kerr, 2002). Hence their complementary use has the potential to lift performance. Let us now consider the potential for complementarity between ISO 9000 and $\mathrm{ABC}$. In the early stages of $\mathrm{ABC}$ development overhead costs are categorized into cost pools. ISO 9000 documentation concerns activities and sets of activities within processes, the necessary components of a formal quality assurance system. Hence they help to identify the drivers of costs or structural determinants of the organization's activities required by $\mathrm{ABC}$. The activities can be associated with related cost pools to generate cost driver rates which help with both costing and cost management revealing economic costs and benefits. The terminology 'cost driver' arose in the $\mathrm{ABC}$ literature, however, rather than being based on only an accounting classification, the ISO 9000 concept helps to highlight the interaction of cost drivers increasing the understanding of cause and effect and promoting steps to greater efficiency through identifying root causes. Interaction of cost drivers will not only occur within an organization but ISO 9000 will encourage analysis of costs and cooperation upstream and downstream within a supply chain. The determination by ISO 9000 systems of major activities linked to managing quality before processing inputs into outputs supports $\mathrm{ABC}$ in determining the consumption of each product, service or customer requirement. Conversely, ABC, in identifying non-value-adding activities leads to an improvement in the ISO 9000 procedures. Furthermore, costing of products or services by using the activity rates and 
the number of activities consumed by those products or services can be undertaken based on activity data derived from ISO 9000 documentation. Customer focus is also central to ISO 9000. This encourages an ABC orientation towards customer costing and profitability in addition to product costing. Such a focus stimulates management accounting information and $\mathrm{ABC}$ to be more strategic and market focused.

Literature also supports the proposition that ISO 9000 and ABC could interact in such a way that they enhance each other's value and effect on performance, in the area of information exchange outlined above. Gupta and Galloway (2003) assert that ABC could support ISO 9000 in identifying the drivers of quality problems and opportunities for improvement as $\mathrm{ABC}$ examines all activities that are truly relevant to production and to determining what portion and value of each resource is consumed (Anderson and Sedatole, 1998; Tsai, 1998; Khataie and Bulgak, 2013). ABC highlights the valuable activities and the non-value activities (Innes and Mitchell, 1995). These non-value activities could, where possible, be eliminated or at least made more efficient, for cost reduction purposes (Anderson and Young, 1999). The information provided by ABC could therefore encourage managers to consider relationships among resources, activities, and cost objects (Horngren et al., 2005) and support managerial judgement with regard to process improvements along the value chain (Porter, 1985). Indeed, in a real case study of ABC use, Huang et.al (2014) showed that when ABC was integrated into a firm's information systems more relevant cost and performance information emerged.

While ISO 9000 and $\mathrm{ABC}$ share some common ground, they are heterogeneous too in terms of specific system objectives. Indeed, ISO 9000 is concerned with quality management and ensuring that "products and services consistently meet customer requirements and that quality is consistently improved" (ISO, 2017). As part of management accounting, the main objective of $\mathrm{ABC}$ is to provide managers with accurate 
activity based cost information that assists in evaluating business process performance and informs operational and strategic decision making (Cooper and Kaplan, 1999; Drury, 2015).

When viewed from the perspective of complementarities in organizations (Milgrom and Roberts, 1995; Ennen and Richter, 2010), the features of ISO 9000 and ABC and the existence of interactions between ISO 9000 and ABC indicate therefore that ISO 9000 and $\mathrm{ABC}$ could be complementary, where the use of $\mathrm{ABC}$ increases the impact of implementation of ISO 9000 on organizational performance. However, while the features of ISO 9000 and ABC could provide opportunities for complementarities between ISO 9000 and $\mathrm{ABC}$, they have to be effectively managed so the two systems complement rather than substitute each other and interact in such a way that they generate the complementarity effect (Milgrom and Roberts, 1995).

Given that for the complementarity effect to occur the levels of all complementary activities need to be raised (Roberts, 2004; Brynjolfsson and Milgrom, 2013), several researchers suggested that a positive correlation between changes in the levels of complementary activities indicates the presence of complementarities and may signal that a coordinated and synchronous approach to managing complementarities has been adopted (Whittington et al., 1999; Bresnahan, et al., 2002; Brynjolfsson and Milgrom, 2013). We therefore propose the following hypothesis:

H1. The extent of ISO 9000 implementation is positively correlated with the extent of $A B C$ use. 
In complementary relationships, the impact of adopting one complementary activity is increased by doing the other one as well (Roberts, 2004). Conversely, adopting only one activity may not generate a significant impact on organizational performance (Roberts, 2004) or may have a negative effect on organizational performance (Whittington et al., 1999). Consequently, organizations that implement complementary activities are likely to demonstrate a stronger positive impact of one of the complementary activities on organizational performance than organizations that implement only one of the complementary activities (Brynjolfsson and Milgrom, 2013). We therefore propose the following hypothesis.

H2. Direct and indirect positive effects of the extent of ISO 9000 implementation on organizational performance are significantly different and stronger for organizations that adopted both ISO 9000 and ABC (ABC Firms) as compared with organizations that adopted only ISO 9000 (Non-ABC Firms).

\section{Research design and methods}

\subsection{Variables and research instrument}

To attain the study aim and to test the two research hypotheses, we measured three latent reflective constructs: the extent of ISO 9000 implementation, the extent of ABC use and organizational performance. Given that our literature review resulted in finding no valid scales that would be suitable for attaining the aim of this study and for testing the hypotheses, we developed new scales that measure the three constructs. Careful attention 
was paid to ensuring content validity of the measures used in this study, as discussed in this section of the paper.

Regarding the extent of ISO 9000 implementation, following an extensive literature review on ISO 9000 and organizational performance, we decided to assess this extent with reference to the ISO 9000 quality management principles. We made this choice because the ISO 9000 principles are intended to guide organizational performance improvement (ISO, 2012; ISO 2015), and thus align with the focus of this study. Furthermore, unlike the ISO 9001 requirements that must be met for an organization to be ISO 9001 certified (ISO, 2016), the implementation of the ISO 9000 quality management principles may significantly vary among the ISO 9001 certified organizations (ISO, 2012; ISO 2015). Such variations in the implementation of ISO 9000 principles and their performance implications have been indicated in empirical results of an exploratory study conducted by Lee et.al (2009). It is for these reasons that this study tests the impact of the extent of ISO 9000 implementation in terms of the ISO 9000 principles. Our literature review showed that a few researchers had previously examined implementation of ISO 9000 with reference to principles (e.g. Lee et al. 2009; Kuncoro, 2013; Bakotić and Rogošić, 2017). However, because of their different study objectives or methodological limitations, we could not use in our research their scales developed for the purposes of their studies. Thus, the extent of ISO 9000 implementation was operationalised using the most recent version of ISO 9000 available at the time (i.e. ISO 9000:2008). Consistent with the 2008 version of the ISO 9000 principles, eight indicators of the latent construct were used, namely customer focus; leadership; involvement of people; process approach; system approach to management; continual improvement; factual approach to decision-making; mutually beneficial supplier relationship (ISO, 2012). Respondents were given a comprehensive glossary of the principles to ensure that each item was understood and hence respondents could identify the extent to which each principle was implemented in their organizations. 
Specifically, respondents were asked to indicate their agreement or disagreement with statements that their organization fully implemented each of the eight principles on a scale from 1 (strongly disagree) to 7 (strongly agree).

Regarding the extent of $A B C$ use, our literature review showed that prior $\mathrm{ABC}$ research used various approaches to assessing $\mathrm{ABC}$ use depending on the particular research question. Some used a dichotomy, use/non-use (Innes and Mitchell, 1995; Banker et. al. 2008) others required respondents to indicate the extent of use along a scale from 1 (non-use) to 5 (extensive use) (Jankala and Silvola, 2012) or in various functional areas, e.g. design, manufacture, (Maiga and Jacobs, 2008). In this research, respondents were first asked whether their organizations adopted activity based costing as defined in the research instrument. Then the respondents were asked about the extent of $A B C$ use in relation to the nine purposes of using ABC, following Cagwin and Bouwman's (2002) approach. The nine indicators of this construct included product costing, cost management, pricing decisions, product mix decisions, determining customer profitability, budgeting, as an off-line analytic tool, outsourcing decisions, and performance measurement.

Respondents were asked to indicate their agreement or disagreement with statements that their organization consistently used $\mathrm{ABC}$ for each of the nine purposes on a scale from 1 (strongly disagree) to 7 (strongly agree).

Organizational performance $(O P)$ is defined here as the outcomes of an organization's action. Based on a review of the specific literature on ISO 9000 and organizational performance and on $\mathrm{ABC}$ and organizational performance, seven indicators of organizational performance were selected for this study because they had been previously used both in research on the impacts of ISO 9000 and performance (e.g. Naveh and Marcus, 2005; Jang and Lin, 2008; Psomas et al., 2013; Fatima, 2014), and in research on the impacts of $\mathrm{ABC}$ and performance (e.g. Ittner et al., 2002; Banker et al., 
2008; Maiga and Jacobs, 2008; Jankala and Silvola, 2012) . These indicators included: increased sales; increased return on assets (ROA); decreased total cost; improved product / service quality; improved reliability; improved process efficiency; improved process effectiveness. Respondents were given a comprehensive glossary of the performance indicators and they were asked to indicate their agreement or disagreement with statements about their organizational performance since obtaining the ISO 9001 certification on a scale from 1 (strongly disagree) to 7 (strongly agree).

The three scales measuring the extent of ISO 9000 implementation, the extent of $A B C$ use and organizational performance were included in a questionnaire that was drafted in English. A question whether the respondent's organization adopted activity based costing was also included with a view to identifying $A B C$ Firms and Non-ABC Firms. Questions about respondents and their organizations' characteristics were also included.

To further increase content validity, the questionnaire was sent for comments to both English and Thai subject expert academics. It was then translated and back-translated to ensure understandability and reliability. The Thai version was then used as a pilot in structured interviews with two Chief Executive Officers, a quality manager, and accountant. A small number of minor revisions were undertaken based on the above process. For the three study constructs (i.e. the extent of ISO 9000 implementation, the extent of $A B C$ use and organizational performance), the final research instrument contained eight, nine and seven indicators respectively measured on a scale from 1 (strongly disagree) to 7 (strongly agree). 


\subsection{Data collection and analysis}

All Thai ISO 9001-registered organizations were selected as the population for this study. Access was gained to potential respondents through the Thai Industrial Standards Institute which carries out national activities in relation to certification and quality of Thai products and services. There were 3,105 ISO-9001-registered organizations in Thailand at the time of the survey (2015). All companies and respondents were affiliated to the Thai Industrial Standards Institute and thus were familiar with ISO 9000 and competent to answer the questionnaire. Telephone calls were made to every organization to identify the most appropriate respondent by name where this was possible. Initially, the questionnaire was targeted at the Chief Executive Officer or Managing Director of the organizations concerned, however respondents were encouraged to identify if another person was more suitable to answer the questionnaire.

Six hundred and nineteen Thai ISO 9001-registered organizations responded to the questionnaire (19.9\%). There were some randomly missing values in 18 responses and because cases with missing data accounted for less than $3 \%$ of total number of cases, these cases they were deleted resulting in 601 (or 19.4\%) useable responses. Among them, 191 cases represented organizations that adopted both ABC and ISO 9000 (ABC Firms), and 410 cases represented organizations that adopted only ISO 9000 (Non-ABC Firms). Given that the structural models studied here contain 16 variables, sample sizes of 191 and 410 are adequate because (1) they exceed the required sample size of 160 as recommended by Nunnally and Bernstein (1994) and Hair et al. (2010); and (2) the ratio (r) of indicators to latent variables (16/3) is 5.33, which according to Boomsma (1982) means that the required sample size is at least 100.

Independent sample t-test was employed to check for significant differences between early and late respondents (Groves, 2006). Our results show no significant 
differences between both groups of respondents $(\mathrm{P}>.05)$. The results of post hoc Harman single factor analysis indicate that common method variance is not a major concern in this study, as the factor explains 33 per cent and 31 per cent of the variance for the ABC-Firms model and for the Non-ABC Firms model respectively.

Among participating organizations, 54.6\% represented the manufacturing sector and $45.4 \%$ the non-manufacturing sector $(45.4 \%)$. In terms of size, $22.1 \%$ were small (employing less than 50 people), $60.1 \%$ were medium (employing between 50 and 250 people), and $17.8 \%$ were large (employing over 250 people). The 601 organizations employed ISO 9000 for an average of 6 years (range from 2 to 12 years). The ABC Firms employed $\mathrm{ABC}$ for an average of 6 years (range from 3 to10 years).

To assess potential complementarity between ISO 9000 and ABC, we tested two hypotheses. To test hypothesis 1 (H1: The extent of ISO 9000 implementation is positively correlated with the extent of $A B C$ use) we employed Pearson's correlation analysis for all pairwise combinations of indicators of the extent of ISO 9000 implementation and indicators of the extent of $A B C$ use, as recommended by Brynjolfsson and Milgrom (2013). For hypothesis 2 (H2: Direct and indirect positive effects of the extent of ISO 9000 implementation on organizational performance are significantly different and stronger for organizations that adopted both ISO 9000 and ABC as compared with organizations that adopted only ISO 9000), we used a multi-group analysis in Structural Equation Modelling (SEM) using AMOS.

Meanwhile, prior to testing the second hypothesis and given that this study employed latent variables (constructs) that had not been previously tested for dimensionality, we conducted an exploratory factor analysis (EFA) in order to explore the factorial structure of the two constructs of interest, i.e. the extent of ISO 9000 implementation, and organizational performance. Confirmatory factor analysis (CFA) using AMOS (maximum 
likelihood method) was then applied for testing the dimensionality of the constructs using two alternative CFA models for each construct: one-factor model and first-order factor model. We examined model fit statistics for the alternative CFA models for each construct using goodness of fit measures to test whether they meet the validity criteria of providing an adequate fit to the data. For the adequate CFA models, we also used CFA to test the convergent and discriminant validity and reliability of the measurements.

Using the results of the CFAs, we then evaluated the descriptive adequacy of the structural models using alternative goodness of fit measures for the two samples (i.e. for ABC Firms and Non-ABC Firms). The models that met the validity criteria of providing an adequate fit to the data were subsequently subjected to the multi-group analysis to test the second hypothesis. Specifically, given the purposes of multi-group analysis (Byrne, 2010), the multi-group analysis was to determine whether or not the structural paths were equivalent for the $\mathrm{ABC}$ Firms and the Non-ABC Firms and, if not, which path coefficients caused the significant differences in organizational performance of the ABC Firms and Non-ABC Firms.

\section{Findings}

Descriptive statistics in Table 1 show that the ABC Firms $(\mathrm{N}=191)$ used extensively activity based costing for all purposes (all observed mean values exceeded the expected mean value of 4 and ranged from 4.39 to 5.26). Furthermore, the ABC Firms $(\mathrm{N}=191)$ and the Non-ABC Firms (N=410) extensively implemented ISO 9000 principles. Interestingly, the observed mean values for the ABC Firms are higher for all ISO 9000 indicators except one (mutually beneficial supplier relationships), which is higher for the Non-ABC Firms. 
Table 1: Extent of ABC use; Extent of ISO implementation; Organizational Performance - descriptive statistics

\begin{tabular}{|c|c|c|c|c|c|c|c|}
\hline \multirow[b]{2}{*}{ Constructs } & \multicolumn{3}{|c|}{$\begin{array}{c}\text { ABC Firms: } \\
\text { Organizations } \\
\text { adopting } \\
\text { both } \mathrm{ABC} \text { and ISO } \\
9000(\mathrm{~N}=191)\end{array}$} & \multicolumn{3}{|c|}{$\begin{array}{l}\text { Non-ABC Firms: } \\
\text { Organizations } \\
\text { adopting } \\
\text { only ISO 9000 } \\
(\mathbf{N}=\mathbf{4 1 0})\end{array}$} & \multirow[t]{2}{*}{\begin{tabular}{|l|} 
t-test \\
p-value
\end{tabular}} \\
\hline & Mean & S.D. & Range & Mean & S.D. & Range & \\
\hline \multicolumn{4}{|l|}{ The extent of ABC use } & & & & \\
\hline Product costing & 5.26 & .91 & $2-7$ & & & & \\
\hline Cost management & 5.08 & 1.01 & $3-7$ & & & & \\
\hline Pricing decisions & 4.63 & 1.15 & $2-7$ & & & & \\
\hline Product mix decisions & 4.39 & 1.18 & $2-7$ & & & & \\
\hline Determine customer profitability & 4.98 & 1.18 & $2-7$ & & & & \\
\hline Budgeting & 5.02 & 1.21 & $2-7$ & & & & \\
\hline As an off-line analytical tool & 5.10 & 1.03 & $3-7$ & & & & \\
\hline Outsourcing decisions & 4.67 & 1.30 & $2-7$ & & & & \\
\hline Performance measurement & 4.74 & 1.13 & $2-7$ & & & & \\
\hline \multicolumn{8}{|l|}{$\begin{array}{l}\text { The extent of ISO } 9000 \\
\text { implementation }\end{array}$} \\
\hline Customer focus & 5.46 & 1.01 & $3-7$ & 4.68 & 1.16 & $2-7$ & $.000 * *$ \\
\hline Leadership & 5.26 & .98 & $2-7$ & 4.98 & 1.09 & $2-7$ & $.002 * *$ \\
\hline Involvement of people & 4.92 & 1.10 & $2-7$ & 4.65 & 1.16 & $2-7$ & $.007 * *$ \\
\hline Process approach & 5.18 & 1.16 & $2-7$ & 4.33 & 1.11 & $2-7$ & $.000 * *$ \\
\hline System approach to management & 5.31 & .97 & $3-7$ & 4.75 & 1.10 & $2-7$ & $.000 * *$ \\
\hline Continual improvement & 5.19 & 1.13 & $2-7$ & 4.88 & 1.07 & $2-7$ & $.001 * *$ \\
\hline $\begin{array}{l}\text { Factual approach to decision- } \\
\text { making }\end{array}$ & 4.72 & 1.25 & $2-7$ & 4.51 & 1.24 & $2-7$ & .058 \\
\hline $\begin{array}{l}\text { Mutually beneficial supplier } \\
\text { relationships }\end{array}$ & 4.85 & 1.23 & $2-7$ & 5.12 & 1.04 & $2-7$ & $.015^{*}$ \\
\hline \multicolumn{8}{|l|}{ Organizational Performance } \\
\hline Increase in sales & 5.05 & .94 & $3-7$ & 5.29 & .97 & $3-7$ & $.004 * *$ \\
\hline Increase in return on assets & 5.30 & .92 & $3-7$ & 5.14 & 1.00 & $2-7$ & .058 \\
\hline Decrease in total costs & 5.00 & .92 & $2-7$ & 5.03 & 1.21 & $2-7$ & .703 \\
\hline $\begin{array}{l}\text { Improved product/service } \\
\text { quality }\end{array}$ & 5.34 & 1.00 & $3-7$ & 4.91 & 1.25 & $2-7$ & $.000 * *$ \\
\hline Improved delivery reliability & 4.88 & .93 & $3-7$ & 4.53 & 1.24 & $2-7$ & $.000 * *$ \\
\hline Improved process efficiency & 5.19 & 1.02 & $3-7$ & 4.88 & 1.32 & $1-7$ & $.002 * *$ \\
\hline Improved process effectiveness & 4.86 & 1.01 & $2-7$ & 4.78 & 1.14 & $2-7$ & .383 \\
\hline
\end{tabular}

Note: The scale ranged from 1 to 7 (strongly disagree to strongly agree)

** significant at the 0.01 level, * significant at the 0.05 level 
The results of a t-test also show significant differences for all but one indicator (factual approach to decision making). Overall, these statistics indicate that firms that adopted both ABC and ISO 9000 implemented most ISO 9000 principles to a greater extent than firms that adopted only ISO 9000. In terms of organizational performance, the observed mean values for the ABC Firms are higher than for the Non-ABC Firms on five out of seven indicators with significant differences observed in relation to: improved product/service quality, improved delivery reliability, and improved process efficiency.

The results of a correlation analysis that tested hypothesis 1 (H1: The extent of ISO 9000 implementation is positively correlated with the extent of $A B C$ use) show that all Pearson's correlations coefficients $r$ between indicators of the extent of ISO 9000 implementation and indicators of the extent of $\mathrm{ABC}$ use are positive. Furthermore, $93.1 \%$ of the coefficients are statistically significant (see Table 2). While the strength of association between the indicators of the extent of ISO 9000 implementation and the extent of $\mathrm{ABC}$ use varies, several interesting patterns can be observed. Firstly, all indicators of the extent of ISO implementation are positively and significantly associated with the extent of $\mathrm{ABC}$ use for the following purposes: product costing, cost management, pricing decision, product mix decisions, determine customer profitability, as an off-line analytical tool, and outsourcing decisions. Secondly, all indicators of the extent of ABC use are positively and significantly associated with the extent of implementing the following ISO principles: customer focus, process approach, continual improvement, factual approach to decision making, and mutually beneficial supplier relationships. Thirdly, some of the strongest associations occur between the following variables: mutually beneficial supplier relationships and outsourcing decisions $(\mathrm{r}=.737, \mathrm{p}<.01)$, customer focus and product costing $(\mathrm{r}=.706, \mathrm{p}<.01)$, factual approach to decision making and product mix decisions $(\mathrm{r}=.700, \mathrm{p}<.01)$, and process approach and cost management $(\mathrm{r}=.664, \mathrm{p}<.01)$ (see Table 2$)$. 
Table 2. Pearson's correlation analysis for indicators of the extent of ISO 9000 implementation and the extent of $\mathrm{ABC}$ use

$\left.\begin{array}{|r|c|c|c|c|c|c|c|c|}\hline \begin{array}{r}\text { Extent of } \\ \text { ISO }\end{array} \\ \begin{array}{r}\text { implementa- } \\ \text { tion }\end{array}\end{array}\right)$

Note: $* *$ correlation is significant at the 0.01 level, * correlation is significant at the 0.05 level

Prior to testing the second hypothesis we have explored and tested the

dimensionality of the study constructs and we have tested convergent and discriminant validity and reliability of the measurements.

In details, regarding the extent of ISO 9000 implementation construct, Bartlett's test of sphericity is significant $(\mathrm{p}<.05)$ with Kaiser-Meyer-Olkin $(\mathrm{KMO})$ index of .85 , which is considered as meritorious. Consequently, the eight indicators of the extent of ISO 9000 implementation construct are used in exploratory factor analysis (EFA). 
Table 3: Results of exploratory and confirmatory factor analysis of the extent of ISO 9000 implementation, and organizational performance (601 firms)

\begin{tabular}{|c|c|c|c|c|}
\hline \multirow{2}{*}{$\begin{array}{l}\text { The extent of ISO } 9000 \\
\text { implementation }\end{array}$} & \multicolumn{3}{|c|}{ Exploratory Factor Analysis } & \multirow{2}{*}{$\begin{array}{c}\text { Confirmatory } \\
\text { Factor } \\
\text { Analysis } \\
\text { Factor } \\
\text { Loading }\end{array}$} \\
\hline & Factor Loading & CICT & $\begin{array}{l}\text { Cronbach's } \\
\text { alpha }\end{array}$ & \\
\hline Factor 1 & & & .84 & \\
\hline Customer focus & .61 & .61 & .81 & .67 \\
\hline Process approach & .80 & .71 & .78 & .82 \\
\hline $\begin{array}{l}\text { System approach to } \\
\text { management }\end{array}$ & .58 & .59 & .82 & .64 \\
\hline Continual improvement & .77 & .72 & .78 & .82 \\
\hline $\begin{array}{l}\text { Factual approach to decision } \\
\text { making }\end{array}$ & .57 & .57 & .83 & .61 \\
\hline Factor 2 & & & .78 & \\
\hline Leadership & .54 & .53 & .70 & .61 \\
\hline Involvement of people & .82 & .71 & .61 & .88 \\
\hline $\begin{array}{l}\text { Mutually Beneficial Supplier } \\
\text { Relationships }\end{array}$ & .73 & .64 & .69 & .75 \\
\hline \multirow{2}{*}{$\begin{array}{l}\text { Organizational } \\
\text { performance }\end{array}$} & \multicolumn{3}{|c|}{ Exploratory Factor Analysis } & \multirow{2}{*}{$\begin{array}{c}\text { Confirmatory } \\
\text { Factor } \\
\text { Analysis } \\
\text { Factor } \\
\text { Loading }\end{array}$} \\
\hline & $\begin{array}{l}\text { Factor } \\
\text { Loading }\end{array}$ & CICT & $\begin{array}{l}\text { Cronbach's } \\
\text { alpha }\end{array}$ & \\
\hline Factor 1 & & & .59 & \\
\hline Increase in sales & .86 & .40 & . & .58 \\
\hline Increase in return on assets & .46 & .40 & . & .70 \\
\hline Factor 2 & & & .86 & \\
\hline Decrease in total costs & .78 & .71 & .82 & .79 \\
\hline $\begin{array}{l}\text { Improved product/service } \\
\text { quality }\end{array}$ & .81 & .74 & .81 & .81 \\
\hline Improved delivery reliability & .81 & .80 & .78 & .88 \\
\hline Improved process efficiency & .31 & . & . & \\
\hline $\begin{array}{l}\text { Improved process } \\
\text { effectiveness }\end{array}$ & .62 & .58 & .86 & .63 \\
\hline
\end{tabular}


The EFA results show that there are two factors with an eigenvalue of 1 or above (4.031 and 1.116 respectively). The cumulative percentage of variance is 64.330 , which exceeds the satisfactory level of 60 percent suggested in the social sciences (Hair et al., 2010). The results of varimax rotation show that factor loadings range from .54 to .82 , thus exceeding the minimum value of .40 as recommended by Hair et al., 2010 (see Table 3). The values of the corrected item-total correlation (CITC) range from .53 to .72 , which are above the satisfactory value of .40 as recommended by Nunnally and Bernstein (1994). The reliability scores of these two factors are .84 and .78 , which is more than the minimum of .50 for EFA as recommended by Nunnally and Bernstein (1994). Table 3 also shows that removal of any indicator would result in a lower Cronbach's alpha or equivalent value. Therefore, all indicators are used in further analysis.

The EFA results indicate therefore that the extent of ISO 9000 implementation is composed of two dimensions: which are named, management principles (MP), and cooperation principles $(\mathrm{CP})$. The emergent two-factor structure of the extent of implementing ISO 9000 principles is consistent with a strand of quality management literature (e.g. Wilkinson, 1992; Flynn et al., 1995; Zu, 2009) that distinguishes between hard/quality management practices (i.e. technical elements of quality management) and soft/infrastructure quality management practices (i.e. behavioural elements that create an environment conducive to the effective use of core quality management practices).

The multidimensional structure of the extent of ISO 9000 implementation is confirmed by the results of the subsequent confirmatory factor analysis (CFA). In terms of convergent validity, results in Table 3 show that all factor loadings for MP and CP exceed .61, which is above the minimum of .50 recommended by Hair et al. (2010). Additionally, in MP and CP constructs, the average variance extracted (AVE) values are .71 and .75 respectively, exceeding the value of .50 , which represents a good overall 
amount of variance in the observed variables accounting for the three constructs (Hair et al., 2010). As for discriminant validity, the average variance extracted (AVE) values of 0.73 exceed the square of correlation estimates of 0.41 . The construct reliability (CR) values of MP and $\mathrm{CP}$ constructs are .80 and .75 , exceeding .60, which provides evidence that indicators that measure each construct have an overall good reliability (Diamantopoulos and Siguaw, 2000).

The CFA model fit statistics for the two-factor extent of ISO 9000 implementation are also within the recommended range (see Table 4). Furthermore, the significant factor loadings range from .61 to .88 and indicate strong associations between each dimension and its indicators. All variances are nonzero $(\mathrm{p}<.05)$, there are no negative variances and no standardized parameter estimate is greater than the value of 1 . Consequently, for the purpose of this study, the extent of ISO 9000 implementation can be considered as a twodimensional construct composed of management principles (MP), and co-operation principles (CP).

Table 4: Confirmatory factor analysis of the extent of ISO 9000 implementation, and organizational performance - model fit indices (601 firms)

\begin{tabular}{|l|l|r|r|}
\hline \multicolumn{1}{|c|}{ Measures } & \multicolumn{1}{|c|}{ Recommended } & \multicolumn{1}{|c|}{$\begin{array}{c}\text { The extent of } \\
\text { ISO 9000 } \\
\text { implementation }\end{array}$} & $\begin{array}{l}\text { Organizational } \\
\text { performance }\end{array}$ \\
\hline $\begin{array}{l}\text { Goodness-of fit statistic } \\
\text { (GFI) }\end{array}$ & $\begin{array}{l}\text { Above } .90 \\
\text { (Hair } \text { et al., 2010) }\end{array}$ & .974 & .981 \\
\hline $\begin{array}{l}\text { The root mean square error } \\
\text { of approximation } \\
\text { (RMSEA) }\end{array}$ & $\begin{array}{l}\text { Below .08 } \\
\text { (MacCallum } \text { et al., 1996) }\end{array}$ & .066 & .074 \\
\hline $\begin{array}{l}\text { The root mean square } \\
\text { residual (RMR) }\end{array}$ & $\begin{array}{l}\text { Below .08 } \\
\text { (Hooper } \text { et al., 2008) }\end{array}$ & .041 & .028 \\
\hline $\begin{array}{l}\text { Comparative fit index } \\
\text { (CFI) }\end{array}$ & $\begin{array}{l}\text { Above } 90 \\
\text { (Bentler, 1992) }\end{array}$ & .974 & .980 \\
\hline $\begin{array}{l}\text { Chi-square( } \chi 2 \text { ) /degrees of } \\
\text { freedom }(\mathrm{df})\end{array}$ & $\begin{array}{l}\text { Below 5.00 } \\
\text { (Wheaton } \text { et al., 1977) }\end{array}$ & 3.583 & 4.308 \\
\hline
\end{tabular}


It should be noted that an alternative one-factor CFA model for the extent of ISO 9000 implementation construct (containing the eight indicators included in this study) has been tested too. However, model fit statistics for this alternative model show that the onefactor model does not meet the validity criteria of providing an adequate fit to the data as the model yielded a $\chi^{2}$ value of 157.635 , with 20 degrees of freedom and a probability of $.000(\mathrm{p}<.05)$, thereby indicating poor fit of the data to the hypothesized model (Byrne, 2010). In addition, the absolute and incremental fit indices for this model consistently deviate from the acceptable fit values (i.e. GFI=.828, RMSEA=.190, RMR=.124, $\mathrm{NFI}=.759, \mathrm{CFI}=.780, \mathrm{TLI}=.692, \mathrm{AGFI}=.691$, chi-square/df=7.822).

Regarding the organizational performance construct, Bartlett's test of sphericity is significant (p-value < .05) with Kaiser-Meyer-Olkin $(\mathrm{KMO})$ index of .787, which is considered as middling. Consequently, the seven indicators of the organizational performance construct were used in exploratory factor analysis (EFA).

The EFA results show that there are two factors with an eigenvalue of 1 or above (3.074 and 1.266 respectively). The cumulative percentage of variance is 62.000 , which exceeds the satisfactory level of 60 percent suggested in the social sciences (Hair et al., 2010). The results of varimax rotation show that one factor loading is below the minimum value of .40 as recommended by Hair et al., 2010 (see Table 3). Consequently, variable "improved process efficiency" is removed from further analysis. The values of the corrected item-total correlation (CITC) range from .40 to .80, which are consistent with the satisfactory value of a minimum of .40 as recommended by Nunnally and Bernstein (1994). The reliability scores of these two factors are .59 and .86 , which is more than the minimum of .50 for EFA as recommended by Nunnally and Bernstein (1994). Table 3 also shows that removal of any indicator for operational performance would result in a lower 
Cronbach's alpha or equivalent value. Therefore, the six indicators are used in further analysis.

The EFA results show therefore that organizational performance is composed of two dimensions: operational performance (OPP), and financial performance (FP). The multidimensional structure of organizational performance is confirmed by the results of the subsequent confirmatory factor analysis (CFA). In terms of convergent validity, results in Table 3 show that all factor loadings for MP and CP exceed .58, which is above the minimum of .50 recommended by Hair et al. (2010). Additionally, the average variance extracted (AVE) values of the FP and OPP constructs are 0.64 and 0.78 , exceeding the value of 0.5 , which represents a good overall amount of variance in the observed variables accounting for two constructs (Hair et al., 2010). As for discriminant validity, the average variance extracted (AVE) values of .71 exceed the square of correlation estimates of 0.12 . The construct reliability (CR) values of the FP and OPP constructs are 0.62 and 0.83 , exceeding 0.60 , which provides evidence that indicators measuring these two constructs have an overall good reliability (Diamantopoulos and Siguaw, 2000).

The CFA model fit statistics for the two-factor organizational performance construct (see Table 4) are also within the recommended range. Furthermore, the significant factor loadings ranging from .58 to .88 indicate strong associations between each dimension and its indicators. All variances are nonzero $(\mathrm{p}<.05)$ with no negative variance and no standardized parameter estimate greater than the value of 1 . Consequently, for the purpose of this study, organizational performance can be considered as a twodimensional construct composed of operational performance (OPP), and financial performance (FP).

An alternative one-factor CFA model for organizational performance (containing the six indicators included in this study) has been tested too. However, model fit statistics 
for this alternative model show that the one-factor model does not meet the validity criteria of providing an adequate fit to the data as the model yielded a $\chi^{2}$ value of 51.208 , with 9 degrees of freedom and a probability of $.000(\mathrm{p}<.05)$, thereby indicating poor fit of the data to the hypothesized model (Byrne, 2010). In addition, most of the absolute and incremental fit indices for this model consistently deviate from the acceptable fit values (i.e. RMSEA=.157, NFI=.785, CFI=.811, TLI=.685, $\mathrm{AGFI=.817,} \mathrm{chi-square/df=5.690).}$

Figure 1. The effects of the extent of ISO 9000 implementation on organizational performance
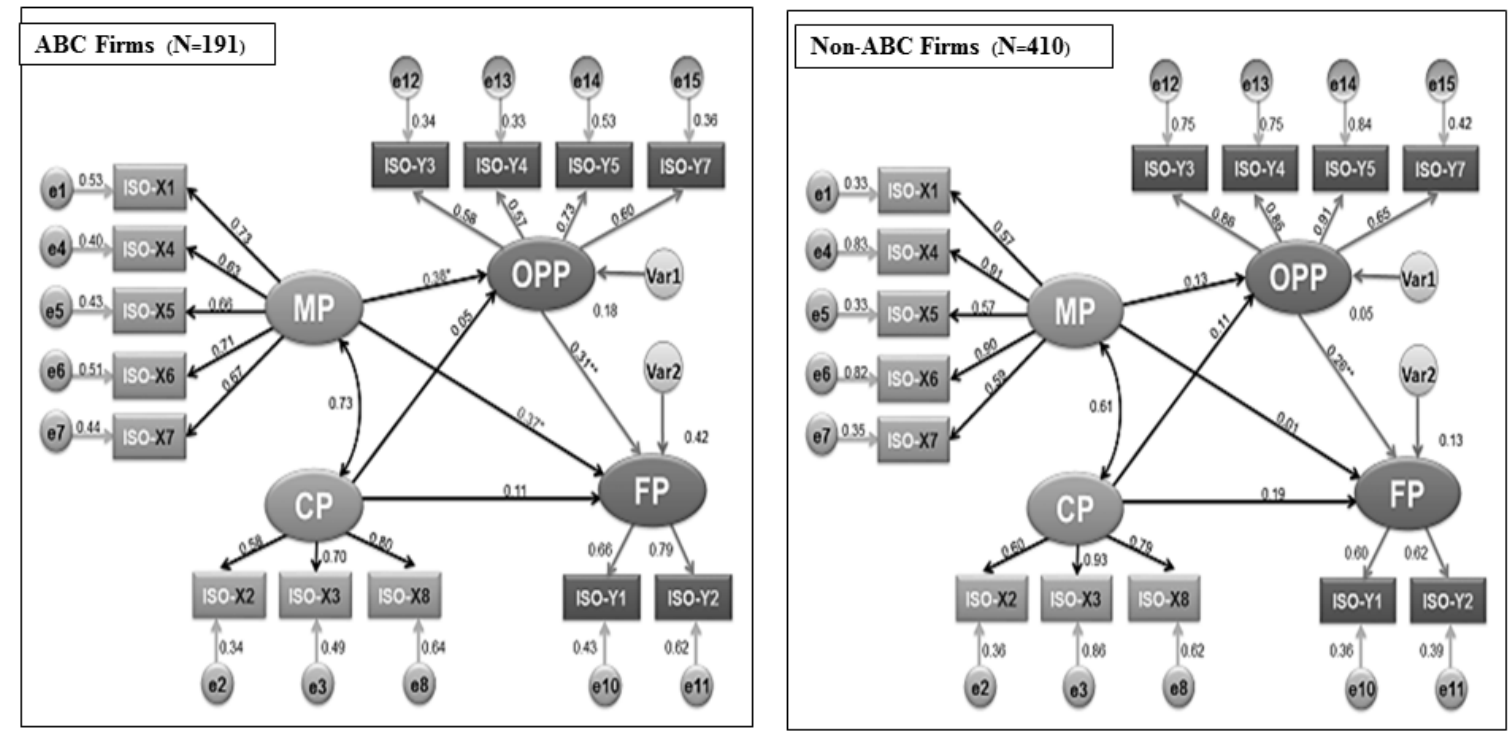

Note: $\mathrm{CP}=$ Cooperation Principles; FP=Financial Performance; MP=Management Principles; $\mathrm{OPP}=$ Operational Performance; ISO-X1=customer focus; ISO-X2=leadership; ISO-X3=involvement of people; ISO-X4=process approach; ISO-X5=system approach to management; ISO$\mathrm{X} 6=$ continual improvement; ISO-X7 = factual approach to decision-making; ISO-X8=mutually beneficial supplier relationships; ISO$\mathrm{Y} 1$ =increase in sales; ISO-Y2=increase in return on assets; ISO-Y3=decrease in total costs; ISO-Y4=improved product/service quality; ISOY5=improved delivery reliability; ISO-Y7=improved process effectiveness; e1-e15=measurement error associated with the observed variables; $\operatorname{Var} 1-\operatorname{Var} 2=$ Residual error in the prediction of unobserved endogenous factor. The models also contains paths coefficient between the factors and the factor loading from the factors to the observed variables; * significant at the 0.05 level; ** significant at the 0.01 level.

The results of EFA and CFA have informed the specification of the structural model that is used for testing the effects of the extent of ISO 9000 implementation on organizational performance on a sample of ABC Firms $(\mathrm{N}=191)$ and Non-ABC Firms $(\mathrm{N}=410)$. The structural model thus comprises four latent variables, i.e. two first-order exogenous latent variables (management principles and co-operation principles), one mediating latent variable (operational performance) and one first-order endogenous latent variable (financial performance) that is influenced directly or indirectly by the exogenous 
latent variables, as shown in Figure 1. The model is over-identified as it has 105 distinct sample moments and 34 parameters to be estimated (5 regression weights, 1 covariance and 18 variances), thereby leaving 71 (105-34) degrees of freedom.

In terms of the descriptive adequacy of the structural model, the SEM results of the goodness of fit tests for the two samples (ABC Firms, and Non-ABC Firms) show that in both cases model fit indices conform to the acceptable fit values for these measures (see Table 5). This indicates that the two samples of data support these models. Furthermore, all variances and covariances are nonzero $(\mathrm{p}<.05)$ and there are no negative variances in either group.

Table 5: Structural model of the extent of ISO 9000 implementation and organizational performance - model fit indices for $\mathrm{ABC}$ firms and Non-ABC firms

\begin{tabular}{|l|l|r|r|}
\hline \multicolumn{1}{|c|}{ Measures } & \multicolumn{1}{|c|}{ Recommended } & $\begin{array}{c}\text { ABC Firms } \\
\text { (N=191) }\end{array}$ & $\begin{array}{c}\text { Non-ABC } \\
\text { Firms } \\
\text { (N=410) }\end{array}$ \\
\hline $\begin{array}{l}\text { Goodness-of fit statistic } \\
\text { (GFI) }\end{array}$ & $\begin{array}{l}\text { Above } .90 \\
\text { (Hair } \text { et al., 2010) }\end{array}$ & .918 & .938 \\
\hline $\begin{array}{l}\text { The root mean square error } \\
\text { of approximation (RMSEA) }\end{array}$ & $\begin{array}{l}\text { Below .08 } \\
\text { (MacCallum } \text { et al., 1996) }\end{array}$ & .066 & .063 \\
\hline $\begin{array}{l}\text { The root mean square } \\
\text { residual (RMR) }\end{array}$ & $\begin{array}{l}\text { Below .08 } \\
\text { (Hooper } \text { et al., 2008) }\end{array}$ & .057 & .054 \\
\hline Comparative fit index (CFI) & $\begin{array}{l}\text { Above } .90 \\
\text { (Bentler, 1992) }\end{array}$ & .924 & .958 \\
\hline $\begin{array}{l}\text { Chi-square( } \chi 2 \text { ) /degrees of } \\
\text { freedom (df) }\end{array}$ & $\begin{array}{l}\text { Below 5.00 } \\
\text { (Wheaton } \text { et al., 1977) }\end{array}$ & 1.834 & 2.625 \\
\hline
\end{tabular}

To test hypothesis 2 (H2: Direct and indirect positive effects of the extent of ISO 9000 implementation on organizational performance are significantly different and stronger for organizations that adopted both ISO 9000 and ABC as compared to organizations that adopted only ISO 9000), the two groups of organizations are now 
subjected to a multi-group analysis in SEM to determine whether or not the structural paths are equivalent for the $\mathrm{ABC}$ Firms and the Non-ABC Firms and, if not, which path coefficients cause the significant differences in organizational performance of the ABC Firms and Non-ABC Firms. Specifically, the multi-group analysis tests for the equivalence of a causal structure involving the effects of the extent of ISO 9000 implementation (MP and $\mathrm{CP}$ ) on operational performance (OPP) and financial performance (FP) across the two groups (ABC-Firms and Non-ABC Firms).

Based on the data in Table 6 that shows goodness-of fit measures for the unconstrained and constrained models, the null hypothesis $\left(\Sigma_{1}=\Sigma_{2}\right.$, where $\Sigma_{1}$ is the population variance-covariance matrix of the $\mathrm{ABC}$ Firms and $\Sigma_{2}$ is the population variance-covariance matrix of the Non-ABC Firms) is rejected. This is because the $\chi^{2}$ difference $\left(\Delta \chi^{2}\right)$ value of 49.055 for the unconstrained and constrained models is statistically significant $(\mathrm{p}<.000)$. Furthermore, as shown in Table 6, the CFI difference $(\triangle \mathrm{CFI})$ value of .01 for the unconstrained and constrained models exceeds the cut-off value of -.01, as recommended by Cheung and Rensvold (2002). This means that one or more structural paths may not be identifying equivalently across the two groups (Byrne, 2010).

Table 6. Goodness-of fit measures for the unconstrained and constrained models (effects of ISO 9000 on organizational performance)

\begin{tabular}{|l|c|c|c|c|c|c|}
\hline \multicolumn{1}{|c|}{ Model } & $\begin{array}{c}\text { No of } \\
\text { Parameters }\end{array}$ & $\begin{array}{c}\text { Chi- } \\
\text { square } \\
\mathbf{(} \boldsymbol{\chi 2} \mathbf{2})\end{array}$ & $\begin{array}{c}\text { Degrees } \\
\text { of } \\
\text { Freedom } \\
\text { (df) }\end{array}$ & $\begin{array}{c}\text { P } \\
\text { Value }\end{array}$ & $\begin{array}{c}\text { Chi- } \\
\text { square } \\
\text { /df }\end{array}$ & $\begin{array}{c}\text { Comparative } \\
\text { fit index } \\
\text { (CFI) }\end{array}$ \\
\hline $\begin{array}{l}\text { Unconstrained } \\
\text { model } \\
\text { (configural) }\end{array}$ & 68 & 316.680 & 142 & .000 & 2.230 & .951 \\
\hline $\begin{array}{l}\text { Structural } \\
\text { weights } \\
\text { (constrained } \\
\text { model) }\end{array}$ & 53 & 365.735 & 157 & .000 & 2.330 & .941 \\
\hline
\end{tabular}


As shown in Figure 1 and Table 7, the statistically different paths for the ABC Firms and the Non-ABC Firms can be observed with regard to the effects of Management Principles (MP) on organizational performance. In detail, MP of organizations that adopted both ABC and ISO 9000 (ABC Firms) have direct significant positive effect on FP ( $\beta$ $=.37, \mathrm{P}=.025)$ and $\mathrm{OPP}(\beta=.38, \mathrm{P}=.023)$. Additionally, they have an indirect significant positive effect on FP through OPP with a total effect of .49 (see Table 7). In contrast, for organizations that adopted only ISO 9000 (Non-ABC Firms), no statistically significant direct or indirect effects of MP on FP can be observed. Indeed, MP of Non-ABC Firms have direct insignificant positive effect on $\mathrm{FP}(\beta=.01, \mathrm{P}=.905)$ and $\mathrm{OPP}(\beta=.13, \mathrm{P}=.069)$. Furthermore, they have an indirect insignificant positive effect on FP through OPP with a total effect of .04 (see Figure 1 and Table 7).

Table 7: Direct, indirect and total impact - ABC Firms and Non-ABC Firms

\begin{tabular}{|c|c|c|c|c|}
\hline $\begin{array}{c}\text { Dependent } \\
\text { construct }\end{array}$ & $\begin{array}{c}\text { Independent } \\
\text { construct }\end{array}$ & $\begin{array}{c}\text { Direct } \\
\text { impact }\end{array}$ & $\begin{array}{c}\text { Indirect } \\
\text { impact }\end{array}$ & $\begin{array}{c}\text { Total } \\
\text { impact }\end{array}$ \\
\hline \multicolumn{5}{|c|}{ ABC Firms $(\mathrm{N}=191)$} \\
\hline \multirow{2}{*}{$\begin{array}{c}\text { FP } \\
\left(\mathrm{R}^{2}=0.42\right)\end{array}$} & MP & $.37 *$ & $.12 *$ & $.49 *$ \\
\hline & $\mathrm{CP}$ & .11 & .02 & .13 \\
\hline \multicolumn{5}{|c|}{ Non-ABC Firms $(N=410)$} \\
\hline \multirow{2}{*}{$\begin{array}{c}\mathrm{FP} \\
\left(\mathrm{R}^{2}=0.13\right)\end{array}$} & MP & .01 & .03 & .04 \\
\hline & $\mathrm{CP}$ & .19 & .03 & .22 \\
\hline
\end{tabular}

Note: $\mathrm{CP}=$ Cooperation Principle; $\mathrm{FP}=$ Financial Performance; $\mathrm{MP}=$ Management principles; * significant at the 0.05 level

In case of both groups (ABC Firms and Non-ABC Firms) no statistically significant direct or indirect effects of Co-operation Principles (CP) on FP can be detected. In detail, $\mathrm{CP}$ of $\mathrm{ABC}$ Firms have direct insignificant positive effect on $\mathrm{FP}(\beta=.11, \mathrm{P}=.454)$ and OPP $(\beta=.05, \mathrm{P}=.741)$; additionally, they have an indirect insignificant positive effect on FP through OPP with a total effect of .13 (see Figure 1 and Table 7). Similarly, CP of 
Non-ABC Firms have direct insignificant positive effect on FP $(\beta=.19, \mathrm{P}=.056)$ and OPP $(\beta=.11, P=.117)$. Additionally, they have an indirect insignificant positive effect on FP through OPP with a total effect of .22 (see Figure 1 and Table 7).

The above results indicate therefore that direct and indirect positive effects of the extent of implementing the ISO 9000 Management Principles on organizational performance are significantly different and stronger for organizations that adopted both ISO 9000 and ABC as compared with organizations that that adopted only ISO 9000. However, the results identified no statistically significant differences regarding the effects of the extent of implementing the ISO 9000 Co-operation Principles. Additionally, the Cooperation Principles (CP) construct of ISO 9000 shows no significant relationship with performance for either the ABC Firms or the Non-ABC Firms.

\section{Discussion}

The results of this study indicate complementarity between the extent of ISO 9000 implementation and the extent of $\mathrm{ABC}$ use because there are positive correlations between indicators of the two constructs (H1) and because the impact of extent of ISO 9000 implementation on organizational performance is significantly different and stronger for ABC Firms than for Non-ABC Firms (H2). This is a significant finding, especially given the sparsity of research into the complementarity of ISO 9000 and ABC.

Specifically, with regard to the first hypothesis, the results of correlation analysis do show that the extent of ISO 9000 implementation is positively correlated with the extent of $\mathrm{ABC}$ use, as recommended by Brynjolfsson and Milgrom (2013). These results resonate with potential complementary links between ISO 9000 and ABC discussed in 
Section 2.3. For example, the greater accuracy claimed for ABC can be used by management to assess detailed product profitability, say in product mix decisions, and this relates to the ISO 9000 principle of a greater factual approach to decision-making. Decision-making also occurs in relation to outsourcing of activities or processes, which supports the ISO 9000 principle concerning supplier relationships, thereby reinforcing the association between ABC and ISO 9000. The important ISO 9000 principle of customer focus feeds into $\mathrm{ABC}$ use by encouraging customer costing and profitability analysis, in addition to product costing. It is increasingly becoming recognized that the traditional approach to costing reinforced a 'silo' (vertical) approach in management thinking, whereas the encouragement of a process (horizontal) orientation promoted by ISO 9000 supports more successful cost management through root cause analysis and $\mathrm{ABC}$.

In this study, most correlations between the extent of ISO 9000 implementation and the extent of $\mathrm{ABC}$ use are statistically significant. Thus the greater the extent of implementation of ISO 9000 principles, the greater the use of $\mathrm{ABC}$ for various purposes, and vice versa. This indicates the likely existence of complementarity between ISO 9000 and $\mathrm{ABC}$. However, the results also show that the strength of association between the indicators of the extent of ISO 9000 implementation and the extent of $\mathrm{ABC}$ varies. This may imply that strength of complementarities between implementation of some ISO 9000 principles and the use of $\mathrm{ABC}$ for various purposes do vary or that a coordinated and synchronous approach to managing complementarities within the $\mathrm{ABC}$ Firms is yet to be fully adopted (Whittington et al., 1999; Brynjolfsson and Milgrom, 2013). This represents an opportunity for further performance improvement to which management should be alerted.

With regard to the second hypothesis, the SEM results show that the extent of ISO 9000 implementation of organizations that use $\mathrm{ABC}$ has a significantly different and a 
much stronger positive impact on organizational performance than organizations that have adopted only ISO 9000. This finding is consistent with the complementarity perspective too because the stronger positive impact of ISO 9000 on organizational performance in the case of $\mathrm{ABC}$ Firms may be indicating the beneficial effects of concurrent implementation of ISO 9000 and ABC and the likely interplay between the extent of ISO 9000 implementation and the extent of $\mathrm{ABC}$ use. Additionally, the weaker impact of ISO implementation on performance of Non-ABC Firms supports the likely complementarity between ISO 9000 and ABC too. Indeed, as Roberts (2004) and Brynjolfsson and Milgrom (2013) noted, if activities are complementary adopting only one of them may not generate a significant impact in organizational performance. The current results thus contrast markedly with the study of Larson and $\operatorname{Kerr}(2002,2007)$, which may be due to significant limitations of their study that were discussed in Section 2.3 of this paper.

The implementation of ISO 9000 has been shown to be a multidimensional construct, so this research specifically identifies the management principles (MP) dimension as having a significant direct effect on operational performance (OPP) and on financial performance (FP). Further, OPP acts as a mediating variable between MP and FP, that is, there is an indirect relationship in evidence which is statistically significant. The implications of this is that the management principles representing the technical aspects of ISO 9000 implementation (i.e. process approach; system approach to management; customer focus; continual improvement; factual approach to decision making) could be emphasized by companies seeking to improve operational and financial performance. It is perhaps these aspects of ISO 9000 that resonate most with ABC systems and could result in improved performance, especially given that the extent of implementation of ISO 9000 principles of process approach, customer focus, continual improvement and factual 
approach to decision making do correlate positively and significantly with the extent of ABC use for all purposes identified in this study, as discussed in Section 4.

The Co-operation Principles (CP) of ISO 9000 that represent the behavioural aspects of ISO 9000 implementation (i.e. leadership; involvement of people; mutually beneficial supplier relationship) shows no significant relationship with performance for either the ABC Firms or the Non-ABC Firms. Nevertheless, in both cases the path coefficients are positive, which is consistent with theory. Given that in SEM the effects are generated by all elements and interactions contained in a model and thus are explicable only by reference to the whole model (Byrne, 2010), and given that the overall model fits the data well both in case of $\mathrm{ABC}$ Firms and Non-ABC Firms, the Co-operation Principles do play a role in generating the positive significant effects of the extent of ISO 9000 implementation on organizational performance.

\section{Conclusion}

\subsection{Summary and theoretical contribution}

Based on a survey of opinions of qualified respondents in ISO 9000-registered companies in Thailand, this study investigated potential complementarity between ISO 9000 and Activity Based Costing (ABC). This was accomplished by examining associations between the extent of ISO 9000 implementation and the extent of ABC use and by examining the impact on organizational performance of the extent of ISO 9000 implementation in organizations that have adopted both ISO 9000 and $\mathrm{ABC}$ (ABC Firms) as compared to those that have only adopted ISO 9000 (Non-ABC Firms). The methodology to capture such impacts, Structural Equation Modelling (SEM), is a holistic 
approach dealing with all components simultaneously and one which is relatively novel in management and accounting research.

The research makes theoretical contributions in a number of respects. The findings of this study provide evidence that deepens our understanding of the roles of ISO 9000 and $\mathrm{ABC}$ in quality management and management accounting research. Specifically, this is the first major empirical study that investigates the potential complementarity between ISO 9000 and $\mathrm{ABC}$ by examining the significant correlations between the indicators of the extent of ISO 9000 implementation and the extent of $\mathrm{ABC}$ use and by examining the significant differences in the impact of ISO 9000 on organizational performance between organizations that adopted ISO 9000 only and organizations that adopted both ISO 9000 and $\mathrm{ABC}$. The results generate new evidence that contributes to closing an important gap in knowledge of complementarity between ISO 9000 and ABC and the direct and indirect effects of the extent of ISO 9000 implementation on organizational performance. The findings have significance for researchers evaluating the use of ISO 9000 and $\mathrm{ABC}$ in concert with other organizational initiatives.

\subsection{Implications for practice}

The results of this study will also be valuable to managers and business consultants who have or are implementing performance improvement systems such as ISO 9000 and ABC. Particularly, the study findings may motivate organizations / practitioners implementing ISO 9000 principles to consider using $\mathrm{ABC}$ in order to exploit the potential complementarity between ISO 9000 and $\mathrm{ABC}$ and to achieve greater organizational performance as this may be an appropriate strategy in developing and running a successful business. 
The findings of the study imply that for the complementarity effect and performance improvement to occur as a result of concurrent extensive application of both ISO 9000 and ABC, cross functional cooperation in firms is required. That is, accountants need to be familiar with the nature of the business, its strategy and the features of its operations so they are able to interpret the significance of the $\mathrm{ABC}$ data to managers. Likewise, managers in all disciplines need to understand the $\mathrm{ABC}$ information and its significance in their functional areas. This is required because as we have discussed earlier, unlike traditional costing systems, the $\mathrm{ABC}$ system benefits from data input from other functions particularly captured within the ISO 9000 system.

\subsection{Limitations and potential for future research}

The findings from over 600 firms give support to the hypotheses presented here. However, there are some limitations which should be acknowledged and these may inform future research into this topic along various dimensions.

While great care was also used in developing the questionnaire and in identification of respondents, the survey used perceptual measures to assess the effect of the extent of ISO 9000 implementation on financial performance. In future research, financial performance could be measured through published financial data to see if similar patterns emerge.

The research focused on all ISO 9000 registered companies in Thailand and the sample obtained may be taken as representative of these. Although the principles of ISO 9000 are international, extending these results to all ISO 9000 registered companies should be undertaken with care. Future research could therefore be conducted in other geographical contexts. 
The study operationalized the extent of ISO 9000 implementation in terms of implementing the ISO 9000 quality management principles. The results of EFA and CFA provided statistical evidence that the extent of ISO 9000 implementation is a twodimensional first-order construct. The two dimensions (MP and CP) were manifested by 4 and 3 indicators (ISO 9000) principles that loaded on their respective factors. Future studies could consider the extent of ISO implementation as second-order constructs comprising seven first order constructs (ISO 9000 principles) with each being measured by several items that manifest these principles. Sufficient sample size would have to be secured to enable testing such complex models in SEM.

This research has examined the potential complementarity between ISO 9000 and $\mathrm{ABC}$ using correlation analysis and a multi-group analysis in structural equation modelling. The multi-group analysis examined significant differences in the effects of the extent of ISO 9000 implementation on organizational performance in organizations that have adopted both ISO 9000 and ABC (ABC Firms) as compared to those that have only adopted ISO 9000 (Non-ABC Firms). Future research could add to the current SEM model the extent of $A B C$ use construct manifested by the indicators used in this study and measured on a continuous scale. This would enable testing the moderating and/or mediating effects of the extent of $A B C$ use as well as examine the construct's direct impact on organizational performance. ${ }^{5}$ Sufficient sample size would have to be secured to enable testing such complex models in SEM.

A quantitative approach was employed in this current study. Further research could, as a step towards advancing our understanding, be undertaken by conducting case studies or in-depth interviews or by using mixed methods.

\footnotetext{
${ }^{5} \mathrm{We}$ are grateful to an anonymous reviewer for the suggestions of further research discussed in this and previous paragraph that represent an alternative conceptual and analytical perspective.
} 
This study investigated potential complementarity between ISO 9000 and ABC only. Future studies could consider potential complementarity between ISO 9000 and other organizational performance improvement initiatives, especially those related to the Cooperative Principles.

This study was conducted using a cross-sectional method. Future studies could consider the use of longitudinal data, as it would be valuable over time to demonstrate a continued causal relationship between the extent of ISO 9000 implementation and organizational performance and complementarity between ISO 9000 and ABC.

Notwithstanding the limitations mentioned above this research provides valid results and generates new evidence that advances our knowledge of complementarity and the effects of ISO 9000 on organizational performance.

\section{References}

Aba, E. K., Badar, M. A. \& Hayden, M. A. (2016). Impact of ISO9001 certification on firms operating performance. International Journal of Quality \& Reliability Management, 33(1), 78-89.

Alic, M., (2014). Impact of ISO 9001 certification cancellation on business performance: a case study in Slovenian organisations. Total Quality Management \& Business Excellence, 25(7) 790-811.

Anderson, S.W. \& Sedatole, K. (1998). Designing quality into products: the use of accounting data in new product development. Accounting Horizons, 12(3), 213-233. 
Anderson, S.W. \& Young, S.M. (1999). The impact of contextual and process factors on the evaluation of activity-based costing systems. Accounting, Organizations and Society, 24(7), 525-559.

Bakotić, D. \& Rogošić, A. (2017). Employee involvement as a key determinant of core quality management practices. Total Quality Management \& Business Excellence, 28, 1209-1226.

Banker, R.D., Bardhan, I.R. \& Chen, T.Y. (2008). The role of manufacturing practices in mediating the impact of activity-based costing on plant performance. Accounting, Organizations and Society, 33(1), 1-19.

Benner, M.J. \& Veloso, F.M. (2008). ISO 9000 practices and financial performance: A technology coherence perspective. Journal of Operations Management, 26(5), 611-629.

Bentler, P.M. (1992). On the fit of models to covariances and methodology to the Bulletin. Psychological Bulletin, 112 (3), 400.

Bescos, P.L. and Charaf, K. (2013). The adoption of ABC and improvement of performance: the case of the central bank of Morocco. Cost Management, 27(4), 27-38.

Boomsma, A. (1982). The robustness of LISREL against small sample sizes in factor analysis models. Systems Under Indirect Observation: Causality, Structure, Prediction, $1,149-173$.

Bresnahan, T.F., Brynjolfsson, E. \& Hitt, L.M. (2002). Information technology, workplace organization, and the demand for skilled labor: Firm-level evidence. The Quarterly Journal of Economics, 117(1), 339-376.

Brynjolfsson, E. \& Milgrom, P. (2013). Complementarity in organizations, in Gibbons, R. and Roberts, J. (Eds.), The Handbook of Organizational Economics, Princeton University Press, Princeton, NJ., 11-55. 
Byrne, B.M. (2010). Structural Equation Modeling with AMOS: Basic Concepts, Applications, and Programming ( $\left.2^{\text {nd }} e d.\right)$, Routledge, New York.

Cagwin, D. \& Bouwman, M.J. (2002). The association between activity-based costing and improvement in financial performance. Management Accounting Research, 13(1), 1-39.

Cheung, G.W. \& Rensvold, R.B. (2002). Evaluating goodness-of-fit indexes for testing measurement invariance. Structural Equation Modeling, 9(2), 233-255.

Chow-Chua, C., Goh, M. \& Boon Wan, T. (2003). Does ISO 9000 certification improve business performance? International Journal of Quality \& Reliability Management, 20 (8), 936-953.

Cooper, R., Kaplan, R.S., Maisel, L.S., Morrissey, E. \& Oehm, R.M. (1992). From ABC to ABM. Management Accounting, 74(5), 54 -57.

Cooper, R. \& Kaplan, R.S. (1999). The Design of Cost Management Systems: Text and Cases, Prentice Hall, New Jersey, U.S.

Dick, G.P., (2000). ISO 9000 certification benefits, reality or myth? The TQM magazine, 12(6), 365-371.

Diamantopoulos, A. \& Siguaw, J.A. (2000), Introducing LISREL: A Guide for the Uninitiated. Sage, London.

Drury, C. (2015), Management and Cost Accounting. Cengage Learning, Andover. Edgeworth, F.Y. (1881), Mathematical Psychics: An Essay on the Application of Mathematics to the Moral Sciences. Kegan Paul, London.

Ennen, E. \& Richter, A. (2010). The whole is more than the sum of its parts —or is it? A review of the empirical literature on complementarities in organizations. Journal of Management, 36(1), 207-233. 
Fatima, M. (2014). Impact of ISO 9000 on business performance in Pakistan: implications for quality in developing countries, The Quality Management Journal, 21(1), 16-24.

Flynn, B.B., Schroeder, R.G., \& Sakakibara, S. (1995). The impact of quality management practices on performance and competitive advantage. Decision Sciences, 26, 659-691.

Gotzamani, K., (2010). Results of an empirical investigation on the anticipated improvement areas of the ISO 9001:2000 standard, Total Quality Management \& Business Excellence, 21(6), 687-704.

Groves, R.M. (2006). Nonresponse rates and nonresponse bias in household surveys. Public Opinion Quarterly, 70, 646-675.

Gupta, M. \& Galloway, K. (2003). Activity-based costing/management and its implications for operations management. Technovation, 23(2), 131-138.

Hair, J.F., Anderson, R.E., Babin, B.J. \& Black, W.C. (2010). Multivariate Data Analysis: A Global Perspective (Vol. 7), Pearson, Upper Saddle River, NJ.

Hardan, A.S. and Shatnawi, T.M. (2013). Impact of applying the ABC on improving the financial performance in telecom companies. International Journal of Business and Management, 8(12), 48-61.

Hooper, D., Coughlan, J. \& Mullen, M. (2008). Structural Equation Modelling: Guidelines for Determining Model Fit. Electronic Journal of Business Research Methods, 6 (1), 53-60.

Horngren, C.T., Sundem, G.L., Stratton, W.O., Burgstahler, D. \& Schatzberg, J. (2005). Introduction to Management Accounting, Prentice, Upper Saddle River, NJ.

Huang, S., Chen, H., Chiu, A. \& Chen C. (2014). The application of the theory of constraints and activity-based costing to business excellence: the case of automotive 
electronics manufacture firms. Total Quality Management \& Business Excellence, 25(5), $532-545$.

Innes, J. \& Mitchell, F. (1995). A survey of activity-based costing in the UK's largest companies. Management Accounting Research, 6(2), 137-153.

Intakhan, P. (2014). ABC success: evidence from ISO 9000 certified companies in Thailand, Asian Review of Accounting, 22(3), 287-303.

ISO (2012). Quality Management Principles, International Organization for Standardization, Geneva.

ISO (2015). Quality Management Principles, available at: https://www.iso.org/files/live/sites/isoorg/files/archive/pdf/en/pub100080.pdf (accessed 11 October 2018)

ISO (2016). Selection and Use of the ISO 9000 Family of Standards, available at: https://www.iso.org/files/live/sites/isoorg/files/store/en/PUB100208.pdf (accessed 12 October 2018).

ISO (2017). ISO 9000 - Quality Management, available at: https://www.iso.org/iso-9001quality-management.html (accessed 8 June 2017).

Ittner, C.D., Lanen, W.N. \& Larcker, D.F. (2002). The association between activity-based costing and manufacturing performance. Journal of Accounting Research, 40(3), 711726.

Jain, S.K. \& Ahuja, I.S. (2012). An evaluation of ISO 9000 initiatives in Indian industry for enhanced manufacturing performance. International Journal of Productivity and Performance Management, 61(7), 778-804. 
Jang, W.Y. \& Lin, C.I. (2008). An integrated framework for ISO 9000 motivation, depth of ISO implementation and firm performance. Journal of Manufacturing Technology Management, 19(2), 194-216.

Jankala, S. \& Silvola, H. (2012). Lagging effects of the use of activity-based costing on the financial performance of small firms. Journal of Small Business Management, 50(3), 498-523.

Kennedy, T. \& Affleck-Graves, J. (2001). The impact of activity-based costing techniques on firm performance. Journal of Management Accounting Research, 13(1), 19-45.

Khataie, A. H. \& Bulgak, A. A. (2013). A cost of quality decision support model for lean manufacturing: activity-based costing application. International Journal of Quality \& Reliability Management, 30(7), 751-764.

Kuncoro, A. (2013) Employing Quality Management Principles to Improve the Performance of Educational Systems: An Empirical Study of the Effect of ISO 9001 Standard on Teachers and Administrators Performance in the Indonesian Vocational Education System. Ph.D. Doctoral Dissertation University of Central Florida, Florida. Available online: http://purl.fcla.edu/fcla/etd/CFE0005019

Kusumah, L. H., \& Fabianto, Y. S. (2018). The differences in the financial performance of manufacturing companies in Indonesia before and after ISO 9000 implementation. Total Quality Management \& Business Excellence, 29(7-8), 941-957.

Larson, P.D. \& Kerr, S.G. (2002). ISO and ABC: complements or competitors? The International Journal of Logistics Management, 13(2), 91-100.

Larson, P.D. \& Kerr, S.G. (2007). Integration of process management tools to support TQM implementation: ISO 9000 and activity-based costing. Total Quality Management \& Business Excellence, 18(1-2), 201-207. 
Lee, P.K., To, W.M. \& Yu, B.T. (2009). The implementation and performance outcomes of ISO 9000 in service organizations: an empirical taxonomy. International Journal of Quality \& Reliability Management, 26(7), 646-662.

MacCallum, R.C., Browne, M.W. \& Sugawara, H.M. (1996). Power analysis and determination of sample size for covariance structure modelling. Psychological Methods, 1 (2), 130-149.

Maiga, A.S. (2014). Assessing self-selection and endogeneity issues in the relation between activity-based costing and performance. Advances in Accounting, 30(2), 251262.

Maiga, A.S. and Jacobs, F.A. (2008). Extent of ABC use and its consequences, Contemporary Accounting Research, 25(2), 533-566.

Milgrom, P. \& Roberts, J. (1994). Complementarities and systems: Understanding Japanese economic organization. Estudios Economicos, 9(1), 3-42.

Milgrom, P. \& Roberts, J. (1995). Complementarities and fit strategy, structure, and organizational change in manufacturing. Journal of Accounting and Economics, 19(2), 179-208.

Miryazdi, S.M. and Jusoh, R. (2015). Activity-based costing diffusion, strategy and organizational performance: evidence from Iran. Asian Journal of Accounting Perspectives, 8, 68-91.

Naveh, E. \& Marcus, A. (2005). Achieving competitive advantage through implementing a replicable management standard: Installing and using ISO 9000. Journal of Operations Management, 24(1), 1-26.

Nunnally, J.C. \& Bernstein I.H. (1994). Psychometric Theory, McGraw Hill, New York. 
Ozkan, S. \& Karaibrahimoglu, Y. Z. (2013). Activity-based costing approach in the measurement of cost of quality in SMEs: a case study. Total Quality Management \& Business Excellence, 24(4) 420-431.

Porter, M.E. (1985). Competitive Advantage: Creating and Sustaining Superior Performance. Free Press, New York.

Psomas, E.L. \& Fotopoulos, C.V. (2009). A meta analysis of ISO 9001: 2000 researchfindings and future research proposals. International Journal of Quality and Service Sciences, 1(2), 128-144.

Psomas, E. L., Pantouvakis, A. \& Kafetzopoulos, D. P. (2013). The impact of ISO 9001 effectiveness on the performance of service companies. Managing Service Quality, 23(2), 149-164.

Roberts, J. (2004). The Modern Firm. Organizational Design for Performance and Growth. Oxford University Press, Oxford.

Tsai, W-H. (1998). Quality cost measurement under activity based costing. International Journal of Quality \& Reliability Management, 15(7), 719-752.

Turney, P.B.B. (1991). Common cents: The ABC performance breakthrough-How to succeed with Activity-based Costing, Hillsboro Or: Cost Technology.

Wheaton, B., Muthen, B., Alwin, D.F. \& Summers, G.F. (1977). Assessing reliability and stability in panel models. Sociological Methodology, 8, 84-136.

Whittington, R., Pettigrew, A., Peck, S., Fenton, E. \& Conyon, M. (1999). Change and complementarities in the new competitive landscape: a European panel study, 1992 1996. Organization science, 10(5), 583-600. 
Wilkinson, A. (1992). The other side of quality: 'soft' issues and the human resource dimension. Total Quality Management, 3, 323-329.

Wu, S.W \& Chen, J.H. (2012). The performance evaluation and comparison based on enterprises passed or not passed with ISO accreditation: An appliance of BSC and ABC methods. International Journal of Quality \& Reliability Management, 29(3), 295-319.

$\mathrm{Zu}, \mathrm{X}$. (2009). Infrastructure and core quality management practices: how do they affect quality? International Journal of Quality and Reliability Management, 26,129-149. 